\section{The demand-control model for job strain: a commentary on different ways to operationalize the exposure variable}

\author{
Modelo demanda-controle de estresse no \\ trabalho: considerações sobre diferentes formas \\ de operacionalizar a variável de exposição
}

\author{
Modelo demanda-control de estrés en el trabajo: \\ consideraciones sobre diferentes formas de \\ operacionalizar la variable de exposición
}

\author{
${ }^{1}$ Instituto de Saúde da \\ Comunidade, Universidade \\ Federal Fluminense, Niterói, \\ Brasil. \\ 2 Instituto de Medicina \\ Social, Universidade do \\ Estado do Rio de Janeiro, \\ Rio de Janeiro, Brasil. \\ Correspondence \\ M. G. M. Alves \\ Instituto de Saúde da \\ Comunidade, Universidade \\ Federal Fluminense. \\ Rua Marquês do Paraná \\ 303, Prédio Anexo, 3o andar, \\ Niterói, RJ 24030-215, Brasil. \\ marciagma@id.uff.br
}

\begin{abstract}
Demand-control has been the most widely used model to study job strain in various countries. However, researchers have used the model differently, thus hindering the comparison of results. Such heterogeneity appears in both the study instrument used and in the definition of the main exposure variable - high strain. This cross-sectional study aimed to assess differences between various ways of operationalizing job strain through association with prevalent hypertension in a cohort of workers (Pro-Health Study). No difference in the association between high job strain and hypertension was found according to the different ways of operationalizing exposure, even though prevalence varied widely, according to the adopted form, from 19.6\% for quadrants to $42 \%$ for subtraction tertile. The authors recommend further studies to define the cutoff for exposure variables using combined subjective and objective data.
\end{abstract}

Psychological Stress; Hypertension; Occupational Exposure

\author{
Márcia Guimarães de Mello Alves 1 \\ Vivianne Melo Braga 2 \\ Eduardo Faerstein 2 \\ Claudia S. Lopes 2 \\ Washington Junger 2
}

\section{Resumo}

O modelo demanda-controle tem sido o mais usado para estudar estresse no trabalho em diversos países. Entretanto, os pesquisadores o utilizam de forma heterogênea, o que tem dificultado a comparação dos resultados dos estudos. Essa heterogeneidade se expressa no instrumento usado e na forma de definir a principal variável de exposição - alta exigência. O objetivo deste estudo seccional foi o de avaliar diferenças entre variadas formas de operacionalização do estresse no trabalho por meio da associação com hipertensão arterial prevalente, numa coorte de trabalhadores (Estudo Pró-Saúde). Não foi encontrada diferença na associação entre alta exigência no trabalho e hipertensão arterial com as diferentes formas de operacionalizar a exposição, ainda que sua prevalência tenha variado bastante, segundo a forma adotada (de 19,6\% [quadrantes] a 42\% [tercil da subtração]). Recomenda-se a realização de novos estudos que definam o ponto de corte para as variáveis de exposição por meio de dados subjetivos e objetivos combinados.

Estresse Psicológico; Hipertensão; Exposição Ocupacional 


\section{Introduction}

Among the existing theoretical models to assess psychosocial strain in the workplace, the demand-control model proposed by Robert Karasek in 19791 has been the most widely used in various countries. The model's premises are: (a) adverse health reactions result from simultaneous exposure to heavy psychological demands and limited control over the work process (highly demanding work, or job strain) $1,2,3$; (b) there is a "positive effect" from stress in the face of elevated psychological demand and control (active jobs). On the contrary, the simultaneous scarcity of psychological demand and control would lead to demotivation, decreased learning, and gradual loss of acquired skills (passive jobs) 1,2,3.

A recent review of the theme identified a wide variety of ways to use available instruments and to define and operationalize the target exposure, which could help explain the inconsistency in results between the various studies 4 . Exposure - high job strain - has been defined by quadrants (combining high demand and low control), the ratio between demand and control, the $\log a$ rithm of the ratio, the interaction term between demand and control scores, and the subtraction between demand and control scores, among others 4 . The outcomes studied with this theoretical model feature cardiovascular diseases and their risk factors, such as arterial hypertension ${ }^{4}$. The results have also been inconclusive, since different meta-analyses have reached diverging conclusions 5,6 . One possible explanation lies in the great variation in the definition of exposure 4,7 .

This study thus aimed to assess potential differences resulting from various ways of operationalizing job strain, by analyzing the association between this exposure and arterial hypertension.

\section{Methods}

The current study was developed as part of the Estudo Pró-Saúde 8, a cohort of technical and administrative employees at a university in Rio de Janeiro, Brazil, and included the employees that participated in phases 1 (1999) and 2 (2001) and had their blood pressure measured $(n=3,226){ }^{9}$.

The instrument used to measure job strain was the Demand, Control, Social Support Questionnaire (DCSQ), adapted to Portuguese within the project's scope ${ }^{9}$. The options for answers in the dimensions "psychological demand" and "control" were presented on a Likert scale (1-4), ranging from "often" to "never/almost never". Each answer was scored from 1 to 4 , classifying items with reverse scores on the two scales. The scores were obtained by adding the items in each dimension, and varied from 5-20 (demand) and 6-24 (control).

Continuous scores were transformed into exposure indicators using the most common approaches found in the literature. High demand was defined by the interval above the upper quantile of the median, tertile, and quartile, and low control as the interval equal to or below the lower quantile of the median, tertile, and quartile. The combination generated the four quadrants. High strain was also defined by the ratio, logarithm of the ratio, and subtraction of the demand and control scores and subsequent classification by quantiles.

The study outcome was arterial hypertension measured in 20019 . We compared the estimates for the association between hypertension and the various ways of operationalizing exposure as long as they combined the scores from the two dimensions. Hypertension was defined as systolic arterial pressure $\geq 140 \mathrm{mmHg}$ and diastolic $\geq 90 \mathrm{mmHg}$ or self-reported use of antihypertensive medication, with an affirmative answer to the question "Have you taken any medication in the last 7 days?" and referring to the complementary open question ("Which?"), categorized as antihypertensive by two independent coders.

Statistical analyses used robust Poisson linear regression. All analyses were performed in the $\mathrm{R}$ software version 2.13 (The R Foundation for Statistical Computing, Vienna, Austria; http:// www.r-project.org).

\section{Ethical issues}

The study was approved by the Institutional Review Board of the Pedro Ernesto University Hospital/ Rio de Janeiro State University (case review n. 224/99).

\section{Results}

Table 1 shows prevalence rates for exposure that combine psychological demand and control on the job, varying from $19.6 \%$ (quadrants) and $42 \%$ (subtraction tertile). The same table shows the prevalence ratios for arterial hypertension according to the different ways of operationalizing exposure. The values are close or equal to one and show no difference between each other. 
Prevalence of exposure for different approaches to operationalizing job strain according to the demand-control model and prevalence ratio (PR) for job strain and arterial hypertension *, with $95 \%$ confidence intervals $(95 \% \mathrm{Cl})$.

\begin{tabular}{|c|c|c|c|c|}
\hline Operationalization & $\mathrm{n}$ & $\%$ & PR & $95 \% \mathrm{Cl}$ \\
\hline Quadrant ** & 3,108 & & & \\
\hline Low strain & 808 & 26.0 & 1.00 & \\
\hline High strain & 609 & 19.6 & 0.98 & $0.81-1.19$ \\
\hline Active & 592 & 19.0 & 1.01 & $0.83-1.23$ \\
\hline Passive & 1,099 & 35.4 & 1.14 & $0.97-1.34$ \\
\hline Continuous ratio *** & 3,108 & & 0.92 & $0.71-1.19$ \\
\hline Tertile ratio & 3,108 & & & \\
\hline High strain & 1,041 & 33.5 & 0.96 & $0.84-1.10$ \\
\hline Quartile ratio & 3,108 & & & \\
\hline High strain & 778 & 25.0 & 0.97 & $0.84-1.12$ \\
\hline Logarithm of continuous ratio & 3,108 & & 0.94 & $0.75-1.18$ \\
\hline Logarithm of tertile ratio & 3,108 & & & \\
\hline High strain & 1,041 & 33.5 & 0.98 & $0.86-1.12$ \\
\hline Logarithm of quartile ratio & 3,108 & & & \\
\hline High strain & 726 & 23.4 & 0.97 & $0.84-1.12$ \\
\hline Continuous subtraction \# & 3,108 & & 1.00 & $0.98-1.01$ \\
\hline Subtraction tertile & 3,108 & & & \\
\hline High strain & 1,306 & 42.0 & 0.94 & $0.83-1.07$ \\
\hline Subtraction quartile & 3,108 & & & \\
\hline High strain & 980 & 31.5 & 0.97 & $0.85-1.11$ \\
\hline
\end{tabular}

* Obtained by robust Poisson linear regression;

** Obtained by median demand plus median control;

*** Obtained by division of demand by control;

\# Obtained by difference between demand and control.

\section{Discussion}

Quadrants are the most traditional way of operationalizing exposure. The categories obtained with this method can present discrepancies due to the cutoff for the psychological demand and control scores. Some authors use the means for the study population or national means. Others set the percentage arbitrarily (most commonly $20 \%) 10$ for the high-risk group (high job strain), but the most widely used way is still the median4, all defined as a function of distribution in the population.

Use of the ratio may also fail to adequately classify exposure, since division of the two numbers may produce the same result when it actually represents different demand and control situations. For example, an individual that scores 10 for demand and 6 for control, both considered low - or conceptually a passive job - shows a ratio of 1.67, while another individual that scores 20 for demand and 12 for control - conceptually a high strain job-obtains the same ratio of 1.67 9,11.
The logarithm of the ratio inherits all the possible errors from the ratio. Likewise, subtraction can also produce an exposure classification error, since there are different values for each dimension that produce the same result when the values are equidistant.

Courvoisier \& Perneger 7 and Campos ${ }^{11}$ considered subtraction the measure that best represents high and low job strain. Schnall et al. 12 did not indicate the best form of operationalization and stated that all forms were associated with the outcome.

Differences reported in the literature on prevalence of job strain suggest the need to assume some classification error in defining exposed versus unexposed and the relationship between the two groups. A possible explanation would be issues related to the instrument's validity, as identified in other studies in Brazil 13,14.

Studies on the relationship between job strain and arterial hypertension have been inconclusive as to the association's statistical significance. The threshold for strain may not be high enough to 
trigger arterial hypertension. This population has already shown interruption of habitual activities 15 , work accidents 16 , and mental disorders 17 . None of these events showed physical alterations, as in an initial phase of the illness process. Studies would be needed to verify biochemical variations in the body as a function of strain, in order to demonstrate such alterations. Campos 11 assessed the variation in salivary cortisol among nursing staff in a public hospital during the work shift and failed to find any association with high strain. All these workers had another precarious job that was not assessed in the study.

The participants in our study were heterogeneous in relation to knowledge areas and work processes, but showed homogeneous employ-

\section{Resumen}

El modelo demanda-control ha sido el más usado para estudiar el estrés en el trabajo en diversos países. No obstante, los investigadores lo utilizan de forma heterogénea, lo que ha dificultado la comparación de los resultados de los estudios. Esa heterogeneidad se expresa en el instrumento usado y en la forma de definir la principal variable de exposición -alta exigencia. El objetivo de este estudio seccional fue el de evaluar las diferencias entre las variadas formas de operacionalización del estrés en el trabajo, mediante la asociación con la hipertensión arterial prevalente, en una cohorte de trabajadores (Estudio Pro-Salud). No se encontraron diferencias en la asociación entre alta exigencia en el trabajo e hipertensión arterial con las diferentes formas de operacionalizar la exposición, pese a que su prevalencia haya variado bastante, según la forma adoptada de 19,6\% (cuadrantes), a 42\% (tercil de la sustracción). Se recomienda la realización de nuevos estudios que definan el punto de corte para las variables de exposición por medio de datos subjetivos y objetivos combinados.

Estrés Psicológico; Hipertensión; Exposición Profesional ment status. Studies comparing populations with stable versus precarious jobs may present different results, and such research is needed.

An alternative and complementary way of assessing job strain would be to simultaneously conduct objective assessments in the workplace, although in population samples, considering other measures besides the workers' own perception of their work environment.

In short, this study was unable to identify the best way to operationalize job strain measured by the DCSQ as the exposure variable. We recommend that future research include a study based on biomarkers for strain to define specific cutoffs for the target population and not only based on the distribution ofDCSQ scores in this population.

\section{Contributors}

M. G. M. Alves and V. M. Braga participated in the article's conceptualization, data analysis and interpretation, and writing and approval of the final version for publication, and were responsible for all aspects of the work in guaranteeing the accuracy and integrity of its components. E. Faerstein and C. S. Lopes participated in the article's conceptualization and writing and approval of the final version for publication. W. Junger participated in the article's conceptualization, data analysis and interpretation, and writing and approval of the final version for publication.

\section{Acknowledgments}

The authors wish to thank the members of the ProHealth Study cohort for their willingness to participate. 


\section{References}

1. Karasek RA. Job demands, job decision latitude and mental strain: implications for job redesign. Adm Sci Q 1979; 24:285-308.

2. Karasek R, Brisson C, Kawakami N, Houtman I, Bongers P, Amick B. The Job Content Questionnaire (JCQ): an instrument for internationally comparative assessments of psychosocial job characteristics. J Occup Health Psychol 1998; 3:322-55.

3. Karasek R, Baker D, Marxer F, Ahlbom A, Theorell T. Job decision latitude, job demands, and cardiovascular disease: a prospective study of Swedish men. Am J Public Health 1981; 71:694-705.

4. Alves MGM, Hökerberg YHM, Faerstein E. Tendências e diversidade na utilização empírica do modelo demanda-controle de Karasek: uma revisão sistemática. Rev Bras Epidemiol 2013; 16:125-36.

5. Hökerberg YHM. Demanda e controle no trabalho e hipertensão arterial: validade dimensional e metanálise [PhD dissertation]. Rio de Janeiro: Instituto de Medicina Social, Universidade do Estado do Rio de Janeiro; 2010.

6. Landsbergis P, Dobson M, Koutsouras G, Schnall P. Job strain and ambulatory blood pressure: a metaanalysis and systematic review. Am J Public Health 2013; 103:e61-e71.

7. Courvoisier DS, Perneger TV. Validation of alternative formulations of job strain. J Occup Health 2009; 52:5-13.

8. Faerstein E, Chor D, Lopes CS, Werneck GL. Estudo Pró-Saúde: características gerais e aspectos metodológicos. Rev Bras Epidemiol 2005; 8:454-66.

9. Alves MGM. Pressão no trabalho: estresse no trabalho e hipertensão arterial em mulheres no Estudo Pró-Saúde [PhD Dissertation]. Rio de Janeiro: Escola Nacional de Saúde Pública, Fundação Oswaldo Cruz; 2004.

10. Karasek R, Choi B, Ostergren PO, Ferrario M, De Smet P. Testing two methods to create comparable scale scores between the job content questionnaire (JCQ) and JCQ-like questionnaires in the European JACE study 2007. Int J Behav Med 2007; 14:189-201.
11. Campos JF. Estresse ocupacional segundo o modelo demanda-controle e suas repercussões na saúde do trabalhador da Enfermagem: análise das variações do cortisol salivar [PhD Dissertation]. Rio de Janeiro: Faculdade de Enfermagem, Universidade do Estado do Rio de Janeiro; 2013.

12. Schnall PL, Pieper C, Schwartz JE, Karasek RA, Schlussel Y, Devereux RB, et al. The relationship between "job strain", workplace diastolic blood pressure, and left ventricular mass index: results of a case-control study. JAMA 1990; 263:1929-35.

13. Griep RH, Rotenberg L, Vasconcellos AG, Landsbergis P, Comaru CM, Alves MG. The psychometric properties of demand-control and effort-reward imbalance scales among Brazilian nurses. Int Arch Occup Environ Health 2009; 82:1163-72.

14. Hökerberg YH, Aguiar OB, Reichenheim M, Faerstein E, Valente JG, Fonseca MJ, et al. Dimensional structure of the demand control support questionnaire: a Brazilian context. Int Arch Occup Environ Health 2010; 83:407-16.

15. Macedo LET, Chor D, Andreozzi V, Faerstein E, Werneck GL, Lopes CS. Estresse no trabalho e interrupção de atividades habituais, por problemas de saúde, no Estudo Pró-Saúde. Cad Saúde Pública 2007; 23: 2327-36.

16. Brito AS. Estresse e acidentes no trabalho: Estudo Pró-Saúde [PhD Dissertation]. Rio de Janeiro: Instituto de Medicina Social, Universidade do Estado do Rio de Janeiro; 2007.

17. Lopes CS, Araya R, Werneck GL, Chor D, Faerstein E. Job strain and other work conditions: relationships with psychological distress among civil servants in Rio de Janeiro, Brazil. Soc Psychiatry Psychiatr Epidemiol 2010; 45:345-54.

Submitted on 24/May/2014

Final version resubmitted on 08/Aug/2014

Approved on 29/Aug/2014 